\title{
Thrombin $\mathrm{Ca}^{2+}$-dependently stimulates protein tyrosine phosphorylation in $\mathrm{BC}_{3} \mathrm{H} 1$ muscle cells
}

\author{
Stefan OFFERMANNS, ${ }^{*}$ Evelyn BOMBIEN and Günter SCHULTZ \\ Institut für Pharmakologie, Freie Universität Berlin, Thielallee 69/73, D-1000 Berlin 33, Germany
}

The proteinase thrombin, known to act via heptahelical Gprotein-coupled receptors, is a mitogenic agent for different cell types, including the mouse muscle cell line $\mathrm{BC}_{3} \mathrm{H} 1$. In this study, the effect of thrombin on tyrosine phosphorylation was examined using anti-phosphotyrosine antibodies. Thrombin was found to induce phosphorylation of $65-70$ and $110-120 \mathrm{kDa}$ proteins in $\mathrm{BC}_{3} \mathrm{Hl}$ cells. The effect of thrombin was concentration-dependent, being half-maximal and maximal at concentrations of 0.03 and $1 \mathrm{unit} / \mathrm{ml}$ respectively. The thrombininduced increase in phosphorylation was rapid $(\leqslant 10 \mathrm{~s})$ and transient, with a peak response after about 1-2 min. The effect of thrombin could be mimicked by the thrombin receptor agonist peptide SFLLRN-NH ${ }_{2}$. Preincubation of cells with pertussis toxin (PT) had no effect on thrombin-induced tyrosine phosphorylation. Epidermal growth factor, platelet-derived growth factor and insulin stimulated tyrosine phosphorylation of different proteins, among which were $65-70$ and $110-120 \mathrm{kDa}$ proteins. The phorbol ester 12-myristate 13-acetate (PMA) as well as the $\mathrm{Ca}^{2+}$ ionophore A23187 both stimulated tyrosine phosphorylation of proteins identical to those phosphorylated by thrombin, suggesting that activation of protein kinase $\mathrm{C}$ (PKC) and elevation of the cytosolic $\mathrm{Ca}^{2+}$ concentration alone are sufficient to induce tyrosine phosphorylation. However, calphostin $\mathrm{C}$ and other PKC inhibitors, which completely inhibited tyrosine phosphorylation induced by PMA, had no influence on the effect of thrombin, whereas loading of cells with the intracellular $\mathrm{Ca}^{2+}$ chelator bis- $\left(O\right.$-aminophenoxy)ethane- $N N N^{\prime} N^{\prime}$ tetra-acetic acid totally blocked thrombin-stimulated tyrosine phosphorylation. Thus tyrosine phosphorylation stimulated by thrombin is an early PT-insensitive cellular response which is either directly mediated by elevation of cytosolic $\mathrm{Ca}^{2+}$ concentration or by a presently unknown mechanism that requires an elevated cytosolic $\mathrm{Ca}^{2+}$ concentration.

\section{INTRODUCTION}

Tyrosine phosphorylation in cellular proteins is considered to be an important mechanism in the regulation of cell proliferation and differentiation. The protein products of several protooncogenes (e.g. p60 c c.src, $\mathrm{p} 150^{\mathrm{c} \cdot a b l}$ ) possess a tyrosine kinase activity (Hunter and Cooper, 1985). Similarly, many receptors for polypeptide growth factors, including epidermal growth factor (EGF), platelet-derived growth factor (PDGF), insulinlike growth factor I and insulin, contain tyrosine-specific protein kinase domains which are activated by ligand binding and are indispensible for the biological activity of the growth factors (Ullrich and Schlessinger, 1990).

Apart from these classic growth factors, several hormones, neuropeptides and vasoactive peptides, known to act via Gprotein-coupled receptors, have also been shown to be stimulators of cell proliferation. Among these are vasopressin, endothelin, bombesin and thrombin (Zachary et al., 1987; Chambard et al., 1987; Takuwa et al., 1989). These peptide agonists bind to distinct receptors and share common second-messenger pathways leading to stimulation of phosphoinositide hydrolysis which again results in the formation of inositol 1,4,5-trisphosphate and diacylglycerol. Both products serve as second messengers by increasing cytosolic free $\mathrm{Ca}^{2+}$ and stimulating protein kinase $\mathrm{C}$ (PKC) respectively.

Recently, several reports showed that some of the peptide hormones mentioned above are able to induce tyrosinephosphorylation events in fibroblasts (Zachary et al., 1991;
Leeb-Lundberg and Song, 1991) and renal mesangial cells (Force et al., 1991). Moreover, in platelets and neutrophils, agonists which act via G-protein-coupled receptors but are not associated with mitogenic processes also lead to tyrosine phosphorylation (Golden and Brugge, 1989; Huang et al., 1990; Dhar et al., 1990; Gomez-Cambronero et al., 1991). Thus the role of tyrosine phosphorylation may not be restricted to proliferation of cells.

The mechanism by which agonists activating G-proteincoupled receptors lead to tyrosine phosphorylation is still unknown. Receptor-independent elevation of cytosolic free $\mathrm{Ca}^{2+}$ concentration and/or activation of PKC by phorbol esters can induce tyrosine phosphorylation in different cell types (Gilmore and Martin, 1983; Ferrell and Martin, 1989; Tsuda et al., 1991). However, it is not clear if these mechanisms are involved in the receptor-dependent effects. Whereas some reports consider an involvement of PKC (Force et al., 1991; Berkow and Dodson, 1991), others favour a role for $\mathrm{Ca}^{2+}$ (Huckle et al., 1990; Huang et al., 1990).

In this work, we studied the effect of thrombin, a serine proteinase with mitogenic effects in different cell types including the murine myocytic cell line $\mathrm{BC}_{3} \mathrm{H} 1$ (Chen and Buchanan, 1975; Kelvin et al., 1989; Pouysségur, 1990), on tyrosine phosphorylation in cellular proteins. We demonstrate that in $\mathrm{BC}_{3} \mathrm{H} 1$ cells thrombin, the receptor of which has been shown to belong to the group of G-protein-coupled receptors (Vu et al., 1991a), stimulates tyrosine phosphorylation of several proteins in a manner dependent of cytosolic $\mathrm{Ca}^{2+}$.

\footnotetext{
Abbreviations used: PMA, phorbol 12-myristate 13-acetate; $\mathrm{H}-7,1$-(5-isoquinolinesulphonyl)-2-methylpiperazine dihydrochloride; PT, pertussis toxin; EGF, epidermal growth factor; PDGF, platelet-derived growth factor; PKC, protein kinase C; BAPTA, bis-(O-aminophenoxy)ethane- $N N N^{\prime} N^{\prime}-$ tetra-acetic acid; BAPTA-AM, bis-(O-aminophenoxy)ethane- $N N N^{\prime} N^{\prime}$-tetra-acetic acid, tetra-acetoxymethyl ester.

* To whom correspondence should be sent.
} 


\section{EXPERIMENTAL}

\section{Materials}

Thrombin, phorbol 12-myristate 13-acetate (PMA), $O$-phosphoL-tyrosine, $O$-phospho-L-serine and $O$-phospho-L-threonine were from Sigma (Deisenhofen, Germany). Calcium ionophore A23187, calphostin $\mathrm{C}$ and bis-( $\mathrm{O}$-aminophenoxy)ethane$N N N^{\prime} N^{\prime}$-tetra-acetic acid tetra-acetoxymethyl ester (BAPTAAM) were purchased from Calbiochem (Frankfurt am Main, Germany), and genistein, 1-(5-isoquinolinesulphonyl)-2-methylpiperazine dihydrochloride $(\mathrm{H}-7)$ and staurosporine were from Gibco (Berlin, Germany). Hirudin was from Serva (Heidelberg, Germany). Pertussis toxin (PT) was from List. ${ }^{45} \mathrm{CaCl}_{2}$ was from New England Nuclear (Bad Homburg, Germany); electrophoresis calibration standards for molecularmass determination were from Pharmacia (Freiburg, Germany).

\section{Cell culture}

Mouse $\mathrm{BC}_{3} \mathrm{H} 1$ cells were obtained from American Type Culture Collection (ATCC). Cells were seeded in $22 \mathrm{~mm}$ wells on Costar 12-well plates in Dulbecco's modified Eagle's medium supplemented with $20 \%(\mathrm{v} / \mathrm{v})$ fetal calf serum in a humidified atmosphere with $7 \% \mathrm{CO}_{2}$ at $37^{\circ} \mathrm{C}$. Cells were used for experiments after they had reached confluency and were serumstarved for about $14-16 \mathrm{~h}$ before the experiments. Before addition of agents, cells were washed once with a buffer containing $138 \mathrm{mM} \mathrm{NaCl}, 6 \mathrm{mM} \mathrm{KCl}, 1 \mathrm{mM} \mathrm{MgCl}, 1 \mathrm{mM} \mathrm{CaCl}, 1 \mathrm{mM}$ $\mathrm{Na}_{2} \mathrm{HPO}_{4}, 5 \mathrm{mM} \mathrm{NaHCO}_{3}, 5.5 \mathrm{mM}$ glucose and $20 \mathrm{mM}$ Hepes/ $\mathrm{NaOH}(\mathrm{pH} 7.4)$ and were allowed to equilibrate in this medium for $30-60 \mathrm{~min}$ at $37^{\circ} \mathrm{C}$.

\section{Antibodies}

Polyclonal anti-phosphotyrosine sera were generated by injecting rabbits with a preparation of phosphotyrosine, glycine and alanine coupled to keyhole limpet haemocyanin (Sigma) using 1-ethyl-3-(3-dimethylaminopropyl)carbodi-imide (Sigma) as described by Kamps and Sefton (1988). Immunoglobulins were precipitated with $40 \%$-satd. $\left(\mathrm{NH}_{4}\right)_{2} \mathrm{SO}_{4}$, resuspended in 0.33 vol. of buffer containing $50 \mathrm{mM}$ Tris $/ \mathrm{HCl}(\mathrm{pH} \mathrm{7.3)}$ and $150 \mathrm{mM} \mathrm{NaCl}$, and dialysed for $48 \mathrm{~h}$ against this buffer (three changes, 100 vol. each). Affinity purification of the dialysates was performed as described by Kamps and Sefton (1988) with the exception that we used phosphotyrosine instead of phosphotyramine in the coupling reaction.

\section{Preparation of cell lysates}

Cells were exposed to ligands at the concentrations and for the durations noted in the Figure legends. Reactions were stopped by adding $100 \mu \mathrm{l}$ of modified ice-cold RIPA buffer [ $150 \mathrm{mM}$ $\mathrm{NaCl}, 10 \mathrm{mM}$ Tris/HCl (pH 8.0), $1 \%$ (w/v) deoxycholic acid, $1 \%(\mathrm{v} / \mathrm{v})$ Nonidet P40, $0.1 \%$ (w/v) SDS, $4 \mathrm{mM}$ EDTA, $1 \mathrm{mM} \mathrm{Na} \mathrm{VO}_{4}, 250 \mu \mathrm{g} / \mathrm{ml}$-nitrophenyl phosphate, $0.2 \mathrm{mM}$ phenylmethanesulphonyl fluoride, $20 \mu \mathrm{g} / \mathrm{ml}$ leupeptin and $20 \mu \mathrm{g} / \mathrm{ml}$ aprotinin]. Cells were immediately scraped off, transferred to reaction tubes containing $50 \mu \mathrm{l}$ of concentrated electrophoresis sample buffer [6\% (w/v) SDS, $18 \%(\mathrm{v} / \mathrm{v}) 2$ mercaptoethanol, $30 \%$ (v/v) glycerol, $1 \mathrm{mM} \mathrm{Na} \mathrm{VO}_{4}$ and a trace amount of Bromophenol Blue dye in $200 \mathrm{mM}$ Tris $/ \mathrm{HCl}$ (pH 7.5)] and incubated for $8 \mathrm{~min}$ at $100^{\circ} \mathrm{C}$. Thereafter, samples were subjected to SDS/PAGE on gels containing $9 \%(w / v)$ acrylamide.

\section{Immunoblotting}

Transfer of proteins on to nitrocellulose filters and detection of phosphotyrosine-containing proteins using anti-phosphotyrosine antibodies and the chemiluminescence (ECL) Western blotting detection system (Amersham, Braunschweig, Germany) have been described (Offermanns et al., 1992). In some experiments, the autoluminograms obtained were analysed by a laser densitometer (LKB 2202 Ultroscan).

\section{${ }^{45} \mathrm{Ca}^{2+}$ effilux}

${ }^{45} \mathrm{Ca}^{2+}$ efflux in $\mathrm{BC}_{3} \mathrm{Hl}$ cells was measured as described by Brown et al. (1984). Confluent cells were loaded with ${ }^{45} \mathrm{CaCl}_{2}(5 \mu \mathrm{Ci} / \mathrm{ml})$ in serum-free medium for 14-16 h. Thereafter individual cultures were transferred to a $37^{\circ} \mathrm{C}$ waterbath and immediately washed four times with a buffer containing $138 \mathrm{mM} \mathrm{NaCl}, 6 \mathrm{mM} \mathrm{KCl}$, $1 \mathrm{mM} \mathrm{MgCl}, 1 \mathrm{mM} \mathrm{CaCl}, 1 \mathrm{mM} \mathrm{Na} \mathrm{HPO}_{4}, 5 \mathrm{mM} \mathrm{NaHCO}$, $5.5 \mathrm{mM}$ glucose and $20 \mathrm{mM}$ Hepes/ $\mathrm{NaOH}$ (pH 7.4). Cells were exposed to the indicated concentrations of thrombin for $2 \mathrm{~min}$. Efflux was terminated by sequential washing with the buffer described above devoid of $\mathrm{MgCl}_{2}$ and supplemented with $3 \mathrm{mM}$ $\mathrm{LaCl}_{3}$. Cells were then dissolved with two rinses of $0.5 \mathrm{ml}$ of $3 \%(w / v)$ Triton X-100 and $10 \mathrm{mM}$ EDTA and transferred to scintillation vials. After addition of $5 \mathrm{ml}$ of scintillation fluid, ${ }^{45} \mathrm{Ca}^{2+}$ content was determined by liquid-scintillation counting.

\section{Reproducibility}

The experiments shown are representative for three or more independently performed experiments.

\section{RESULTS}

When $\mathrm{BC}_{3} \mathrm{H} 1$ cells were incubated with thrombin, several proteins showed enhanced tyrosine phosphorylation. Simulated phosphorylation was found in proteins with relative molecular masses of 65-70 and 110-120 kDa, which showed little constitutive phosphorylation (Figure 1a). Tyrosine phosphorylation was analysed by immunoblotting with anti-phosphotyrosine

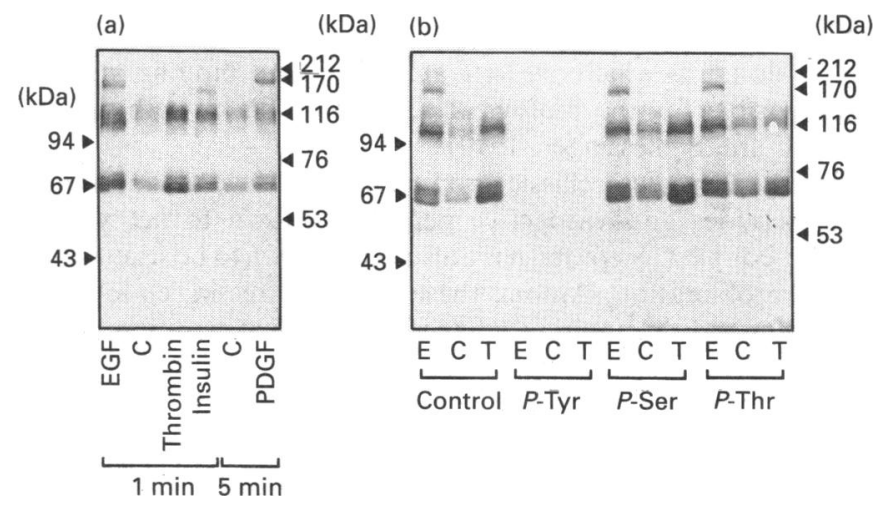

Figure 1 Tyrosine phosphorylation stimulated by thrombin and different polypeptide growth factors in $\mathrm{BC}_{3} \mathrm{H1}$ cells and specificity of the polyclonal affinity-purified anti-phosphotyrosine antibodies for phosphotyrosine

(a) $\mathrm{BC}_{3} \mathrm{H} 1$ cells were incubated in the absence or presence of $20 \mathrm{nM} \mathrm{EGF}, 1$ unit/ml thrombin, $20 \mathrm{nM}$ insulin and $20 \mathrm{nM}$ PDGF for 1 or 5 min as indicated. Proteins were analysed as described in the Experimental section. The autoluminogram of a blot is shown. (b) $\mathrm{BC}_{3} \mathrm{H} 1$ cells were incubated with $20 \mathrm{nM} \mathrm{EGF} \mathrm{(E)} \mathrm{or} 1$ unit/ml thrombin (T) for $1 \mathrm{~min}$. Protein separation and Western blotting on to nitrocellulose filters were performed as described. Filters were cut and incubated with anti-phosphotyrosine antibodies alone (control) or in the presence of $3 \mathrm{mM}$ phosphotyrosine $(P$-Tyr), $3 \mathrm{mM}$ phosphoserine ( $P$-Ser) or $3 \mathrm{mM}$ phosphothreonine $(P$-Thr). Autoluminograms of the blots are shown. Numbers on the left and right margins indicate molecular masses of standard proteins $(\mathrm{kDa})$. C, control (without agonist). 

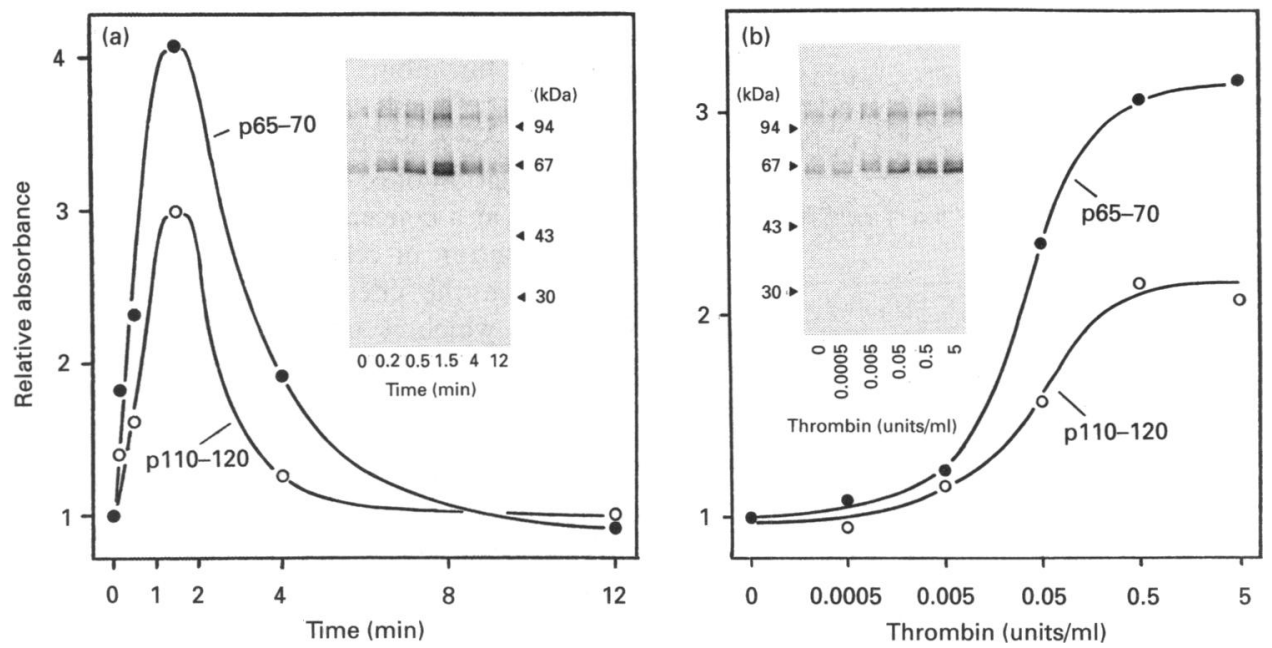

Figure 2 Time course and concentration-dependence of thrombin-induced tyrosine phosphorylation in $\mathrm{BC}_{3} \mathrm{H} 1$ cells

Cells were incubated with 1 unit/ml thrombin for the indicated time periods (a) or with thrombin at the indicated final concentration for $90 \mathrm{~s}$ (b). Samples were processed as described in the Experimental section. The films obtained were quantified by laser scanning densitometry. The absorbance at time 0 or in the absence of thrombin was arbitrarily taken as 1.0. Densitometric analyses of p65-70 (O) and p110-120 (O) are shown. Values are means from three experiments varying by less than $12 \%$. The insets show representative autoluminograms with the molecular masses $(\mathrm{KDa})$ on the right or left margins.

antibodies. Proteins of the same molecular masses were tyrosinephosphorylated by EGF, PDGF and insulin (Figure 1a). These growth factors induced tyrosine phosphorylation of additional proteins with molecular masses of $175 \mathrm{kDa}(\mathrm{EGF}), 145 \mathrm{kDa}$ (insulin) and $180 \mathrm{kDa}$ (PDGF), which in part may represent the autophosphorylated receptors of EGF (175 kDa) and PDGF $(180 \mathrm{kDa})$ (Yarden and Ullrich, 1988).

In order to determine whether the thrombin- and EGFsimulated phosphoproteins were specifically recognized on phosphotyrosine residues, the competitive effect of excess free phosphotyrosine, phosphoserine and phosphothreonine on the anti-phosphotyrosine antibody immunoreaction was examined. As demonstrated in Figure 1(b), binding of the antibodies to the immunoblot was entirely prevented by preincubation with $3 \mathrm{mM}$ phosphotyrosine but not with $3 \mathrm{mM}$ phosphothreonine or phosphoserine, indicating that these protein species indeed undergo increased tyrosine phosphorylation in response to the stimuli. This is additionally supported by the finding that the tyrosine kinase inhibitor genistein (Akiyama and Ogawara, 1991) was able to inhibit thrombin-stimulated phosphorylation (results not shown).

Stimulation of tyrosine phosphorylation of 65-70 and $110-120 \mathrm{kDa}$ proteins by thrombin was rapid and transient (Figure 2a). Enhanced incorporation of phosphate into tyrosine residues was detectable about 10-15 $\mathrm{s}$ after addition of thrombin and reached a maximum after 1-2 min. Thereafter, incorporation declined, and after 10-12 min basal values were reached.

Thrombin concentration-dependently stimulated tyrosine phosphorylation of 65-70 and 110-120 kDa proteins (Figure 2b). Stimulation was significant at concentrations of about $0.003 \mathrm{unit} / \mathrm{ml}$. Half-maximal and maximal effects of thrombin were obtained at concentrations of $0.03 \mathrm{unit} / \mathrm{ml}$ and $1 \mathrm{unit} / \mathrm{ml}$ respectively. The potency of thrombin showed no difference with regard to phosphorylation of 65-70 and 110-120 kDa proteins but maximally stimulated phosphorylation of $65-70 \mathrm{kDa}$ proteins was about twice that of $110-120 \mathrm{kDa}$ proteins.

The thrombin receptor was recently cloned and shown to belong to the group of heptahelical G-protein-coupled receptors
Table 1 Influence of hirudin on tyrosine phosphorylation stimulated by thrombin and the effect of a thrombin receptor agonist peptide on tyrosine phosphorylation in $\mathrm{BC}_{3} \mathrm{H1}$ cells

Upper part: cells were incubated with $0.2 \mathrm{unit} / \mathrm{ml}$ thrombin in the absence or presence of $1 \mathrm{unit} / \mathrm{ml}$ hirudin for $1 \mathrm{~min}$. Lower part: cells were incubated with 1 unit/ml thrombin or increasing concentrations of the thrombin receptor against peptide SFLLRN-NH ${ }_{2}$ for 1 min Samples were processed as described in the Experimental section. The densitometry of the 65-70 and 110-120 kDa region of autoluminograms was performed with a laser densitometer (LKB 2202 Ultroscan). The absorbance of controls (vehicle only added) was arbitrarily taken as 1.0. The results of three independently performed experiments are shown. Each value represents the mean \pm S.E.M.

\begin{tabular}{|c|c|c|}
\hline \multirow[b]{2}{*}{ Condition } & \multicolumn{2}{|c|}{$\begin{array}{l}\text { Densitometric evaluation } \\
\text { of autoradiogram } \\
\text { (relative to control) }\end{array}$} \\
\hline & p65-70 & p110-120 \\
\hline Control & 1 & 1 \\
\hline Thrombin (0.2 unit/ml) & $2.62 \pm 0.28$ & $2.08 \pm 0.16$ \\
\hline Hirudin (1 unit/ml) & $0.95 \pm 0.12$ & $1.04 \pm 0.14$ \\
\hline Hirudin + thrombin & $1.22 \pm 0.13$ & $1.19 \pm 0.10$ \\
\hline Thrombin (1 unit/ml) & $2.83 \pm 0.25$ & $2.11 \pm 0.21$ \\
\hline Control & 1 & 1 \\
\hline SFLLRN-NH ${ }_{2}(0.1 \mu \mathrm{M})$ & $1.03 \pm 0.06$ & $1.14 \pm 0.13$ \\
\hline SFLLRN-NH ${ }_{2}(1 \mu \mathrm{M})$ & $1.82 \pm 0.18$ & $1.40 \pm 0.11$ \\
\hline SFLLRN-NH ${ }_{2}(10 \mu \mathrm{M})$ & $2.81 \pm 0.16$ & $1.99 \pm 0.22$ \\
\hline SFLLRN-NH ${ }_{2}(100 \mu \mathrm{M})$ & $2.69 \pm 0.23$ & $1.96 \pm 0.18$ \\
\hline
\end{tabular}

with the notable exception that the receptor is activated by the serine proteinase activity of thrombin ( $\mathrm{Vu}$ et al., 1991a). We therefore tested whether the potent thrombin inhibitor hirudin (Markwardt, 1970) can prevent thrombin from stimulating tyrosine phosphorylation. The thrombin inhibitor hirudin totally blocked the effect of thrombin (Table 1). In order to further confirm that thrombin exerted its effect via its G-protein-coupled receptor we applied the hexapeptide SFLLRN-NH ${ }_{2}$, representing 
Table 2 Effect of PT on tyrosine phosphorylation stimulated by increasing concentrations of thrombin

Cells were preincubated with vehicle or $100 \mathrm{ng} / \mathrm{ml}$ PT for $24 \mathrm{~h}$. Thereafter, cells were stimulated with increasing concentrations of thrombin for $1 \mathrm{~min}$ as indicated. Densitometry of the 65-70 and $110-120 \mathrm{kDa}$ regions of autoluminograms was performed as described in Table 1.

Densitometric evaluation of autoradiogram (relative to control)

\begin{tabular}{lll}
\cline { 2 - 3 } Condition & p65-70 & p110-120 \\
\hline Control & 1 & 1 \\
Thrombin (0.001 unit/ml) & $1.12 \pm 0.08$ & $1.16 \pm 0.04$ \\
Thrombin (0.01 unit/ml) & $1.38 \pm 0.12$ & $1.48 \pm 0.14$ \\
Thrombin (0.1 unit/ml) & $2.53 \pm 0.33$ & $1.92 \pm 0.20$ \\
Thrombin (1 unit/ml) & $2.93 \pm 0.25$ & $2.21 \pm 0.31$ \\
PT & $0.92 \pm 0.09$ & $1.10 \pm 0.06$ \\
PT + thrombin (0.001 unit/ml) & $1.08 \pm 0.07$ & $1.18 \pm 0.13$ \\
PT + thrombin $(0.01$ unit/ml) & $1.46 \pm 0.16$ & $1.40 \pm 0.10$ \\
PT + thrombin $(0.1$ unit/ml) & $2.41 \pm 0.21$ & $1.82 \pm 0.12$ \\
PT + thrombin (1 unit/ml) & $2.74 \pm 0.19$ & $2.17 \pm 0.18$
\end{tabular}

Table 3 Effect of calphostin C on tyrosine phosphorylation stimulated by thrombin and PMA

Cells were preincubated in the absence or presence of calphostin $\mathrm{C}(3 \mu \mathrm{M})$ for $10 \mathrm{~min}$. At the end of this period, thrombin ( $1 \mathrm{unit} / \mathrm{ml})$ or PMA $(100 \mathrm{ng} / \mathrm{ml})$ was added and cells were incubated for 1 and 3 min respectively. Densitometry of the 65-70 and 110-120 kDa regions of autoluminograms was performed as described in Table 1.

Densitometric evaluation of autoradiogram (relative to control)

\begin{tabular}{lll}
\cline { 2 - 3 } Addition & p65-70 & p110-120 \\
\hline Control & 1 & 1 \\
Thrombin $(1 \mathrm{unit} / \mathrm{ml})$ & $2.73 \pm 0.34$ & $2.01 \pm 0.21$ \\
PMA $(100 \mathrm{ng} / \mathrm{ml})$ & $2.88 \pm 0.41$ & $1.86 \pm 0.15$ \\
Calphostin C $(3 \mu \mathrm{M})$ & $0.97 \pm 0.06$ & $0.88 \pm 0.08$ \\
Thrombin + calphostin C & $2.90 \pm 0.47$ & $1.83 \pm 0.12$ \\
PMA + calphostin C & $0.88 \pm 0.18$ & $0.85 \pm 0.10$
\end{tabular}

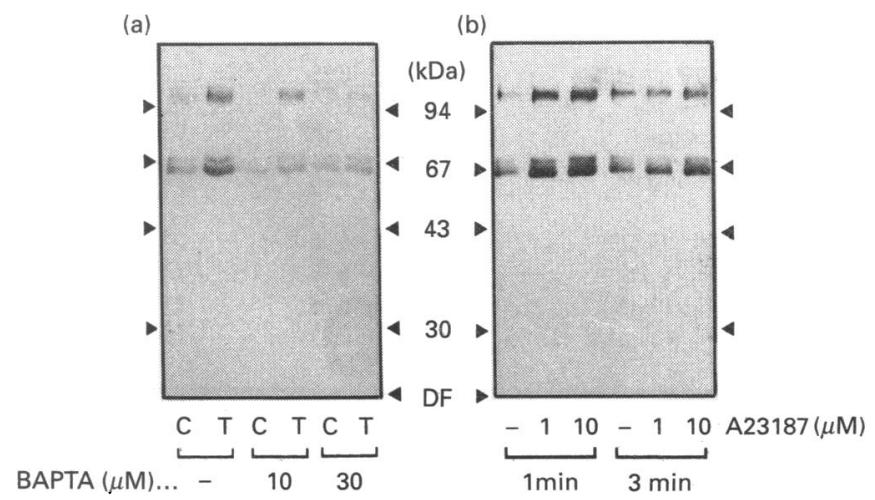

Figure 3 Influence of A23187 on tyrosine phosphorylation and effect of BAPTA on thrombin-stimulated tyrosine phospherylation in BCy $\mathrm{H1}$ cells

(a) $\mathrm{BC}_{3} \mathrm{H} 1$ cells were preincubated for $20 \mathrm{~min}$ in the absence or presence of 10 and $30 \mu \mathrm{M}$ BAPTA-AM and were then incubated for $1 \mathrm{~min}$ with $1 \mathrm{unit} / \mathrm{ml}$ thrombin $(\mathrm{T}) ; \mathrm{C}$, control (without stimulus). (b) Cells were incubated with 1 and $10 \mu \mathrm{M} \mathrm{A23187} \mathrm{or} \mathrm{vehicle} \mathrm{for} 1$ or $3 \mathrm{~min}$. Proteins were analysed as described in the Experimental section. Autoluminograms of the blots are shown. Numbers in the middle refer to both autoluminograms and indicate molecular masses of marker proteins $(\mathrm{kDa})$; DF, dye front the new $\mathrm{N}$-terminus of the proteolytically activated thrombin receptor (Vu et al., 1991b). This peptide has recently been shown to induce thrombin receptor activation (Hui et al., 1992). Incubation of cells with increasing concentrations of the receptor agonist peptide also led to a stimulation of tyrosine phosphorylation of 65-70 and 110-120 kDa proteins with maximal effects at a concentration of $10 \mu \mathrm{M}$ (Table 1).

Preincubation of cells with PT ( $100 \mathrm{ng} / \mathrm{ml}$ for $24 \mathrm{~h})$ had no influence on the effect of different thrombin concentrations (Table 2), which is consistent with the involvement of PTinsensitive G-proteins. In membranes prepared from PTpretreated cells at the same time as phosphorylation assays were performed, PT was unable to incorporate ${ }^{32} \mathrm{P}$-labelled ADPribose (not shown), verifying the efficiency of the pretreatment procedure.

We further studied effector systems which are possibly involved in the thrombin-dependent stimulation of tyrosine phosphorylation. Activation of the thrombin receptor is recognized to result in the hydrolysis of inositol phospholipids with the release of inositol 1,4,5-trisphosphate, a consecutive increase in cytoplasmic $\mathrm{Ca}^{2+}$ concentration and activation of PKC (Fain et al., 1988; Meldrum et al., 1991). Direct activation of PKC by the addition of PMA resulted in tyrosine phosphorylation of proteins with identical molecular masses as seen in response to thrombin (Table 3). This may suggest that activation of PKC alone is sufficient to induce tyrosine phosphorylation in $\mathrm{BC}_{3} \mathrm{Hl}$ cells. As expected, preincubation of cells with the specific PKC inhibitor, calphostin C (Tamaoki, 1991), totally suppressed the effect of PMA (Table 3). However, the stimulation of tyrosine phosphorylation via thrombin was not influenced by calphostin C. Likewise, preincubation of cells with other PKC inhibitors (e.g. staurosporine, $\mathrm{H}-7$ ) as well as down-regulation of PKC activity by treating the cells with a high concentration of PMA for $24 \mathrm{~h}$ did not affect the thrombin-stimulated tyrosine phosphorylation (not shown). Although activation of PKC had a similar effect on tyrosine phosphorylation to that of thrombin, the effect of thrombin is obviously not mediated by PKC. Thus there are PKC-dependent and -independent pathways which lead to tyrosine phosphorylation in $\mathrm{BC}_{3} \mathrm{H} 1$ cells.

To test the role of cytosolic $\mathrm{Ca}^{2+}$ in the effect of thrombin on tyrosine phosphorylation, $\mathrm{BC}_{3} \mathrm{H} 1$ cells were treated with the $\mathrm{Ca}^{2+}$ ionophore A23187. A23187 ( 1 and $10 \mu \mathrm{M}$ for $1 \mathrm{~min}$ ) induced tyrosine phosphorylation of proteins with relative molecular masses identical with those found after addition of thrombin (Figure 3). The effect of A23187 was reduced after 3 min, thus roughly resembling the effect of thrombin, including the time course. If the increase in tyrosine phosphorylation is secondary to an elevation in cytosolic $\mathrm{Ca}^{2+}$ concentration, blocking the $\mathrm{Ca}^{2+}$ increase should inhibit the ability of thrombin to stimulate tyrosine phosphorylation. In order to prevent an increase in cytosolic $\mathrm{Ca}^{2+}$ after addition of thrombin, cells were preincubated with BAPTA-AM which, after entering the cell, is hydrolysed into the active $\mathrm{Ca}^{2+}$ chelator BAPTA. BAPTA-AM $(30 \mu \mathrm{M})$ totally inhibited the thrombin-stimulated tyrosine phosphorylation of 65-70 and 110-120 kDa proteins by thrombin (Figure 3 and Table 4), whereas the effects of EGF, insulin and PDGF on tyrosine phosphorylation of 65-70 and 110-120 kDa proteins were not inhibited by BAPTA-AM (Table 4). Incubation of $\mathrm{BC}_{3} \mathrm{H} 1$ cells with thrombin in a buffer devoid of $\mathrm{Ca}^{2+}$ but supplemented with $3 \mathrm{mM}$ EDTA had no significant effect on the action of thrombin, suggesting that intracellular $\mathrm{Ca}^{2+}$ rather than extracellular $\mathrm{Ca}^{2+}$ may be involved in the response to thrombin. To confirm further that the PT-insensitive tyrosine phosphorylation induced by thrombin may be related to mobilization of $\mathrm{Ca}^{2+}$ in $\mathrm{BC}_{3} \mathrm{H} 1$ cells, we tested whether thrombin 
Table 4 Effect of BAPTA on tyrosine phosphorylation stimulated by thrombin and different polypeptide growth factors

Cells were preincubated for $20 \mathrm{~min}$ in the absence or presence of $30 \mu \mathrm{M}$ BAPTA-AM. Thereafter, cells were incubated for 1 min with 1 unit/ml thrombin, $20 \mathrm{nM} \mathrm{EGF,} 20 \mathrm{nM}$ insulin or for $5 \mathrm{~min}$ with $20 \mathrm{nM}$ PDGF. Densitometry of autoluminograms was performed as described in Table 1.

\begin{tabular}{lll}
\hline & \multicolumn{2}{l}{$\begin{array}{l}\text { Densitometric evaluation of autoradiogram } \\
\text { (relative to control) }\end{array}$} \\
\cline { 2 - 3 } Condition & $\mathrm{p} 65-70$ & $\mathrm{p} 110-120$ \\
\hline Control & 1 & 1 \\
Thrombin $(1 \mathrm{unit} / \mathrm{ml})$ & $3.16 \pm 0.25$ & $2.24 \pm 0.31$ \\
EGF $(20 \mathrm{nM})$ & $2.73 \pm 0.26$ & $1.85 \pm 0.15$ \\
Insulin $(20 \mathrm{nM})$ & $2.18 \pm 0.19$ & $1.89 \pm 0.12$ \\
PDGF $(20 \mathrm{nM})$ & $2.06 \pm 0.21$ & $1.65 \pm 0.09$ \\
BAPTA-AM $(30 \mu \mathrm{M})$ & $0.92 \pm 0.09$ & $1.10 \pm 0.06$ \\
BAPTA-AM + thrombin & $1.08 \pm 0.07$ & $1.18 \pm 0.13$ \\
BAPTA-AM + EGF & $2.54 \pm 0.18$ & $1.78 \pm 0.16$ \\
BAPTA-AM + insulin & $2.27 \pm 0.32$ & $1.69 \pm 0.08$ \\
BAPTA-AM + PDGF & $1.98 \pm 0.15$ & $1.49 \pm 0.07$ \\
\hline
\end{tabular}

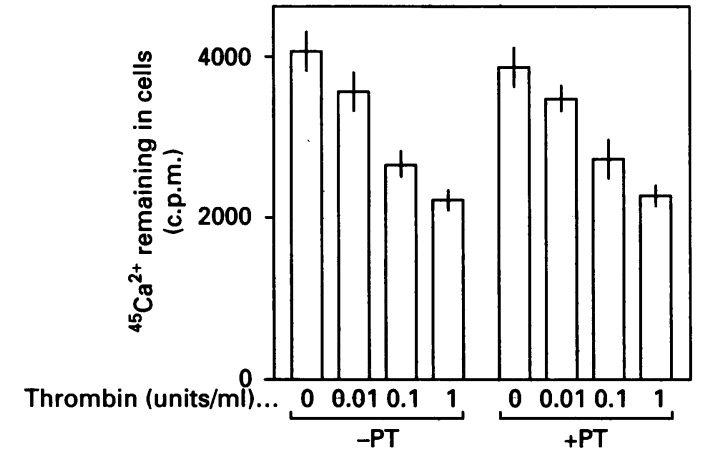

Figure 4 Effect of PT on thrombin-induced ${ }^{45} \mathrm{Ca}^{2+}$ efflux in $\mathrm{BC}_{3} \mathrm{H1}$ cells

Control cells $(-P T)$ or cells treated with $100 \mathrm{ng} / \mathrm{mt}$ PT for $24 \mathrm{~h}(+\mathrm{PT})$ were loaded with ${ }^{45} \mathrm{Ca}^{2+}$ as described in the Experimental section. Cell-associated $\mathrm{Ca}^{2+}$ efflux after a $2 \mathrm{~min}$ incubation in the absence or presence of increasing thrombin concentrations was measured as described. Values represent mean values \pm S.E.M. of triplicates.

caused PT-insensitive $\mathrm{Ca}^{2+}$ mobilization (Figure 4). In control cells as well as in PT-treated cells, thrombin caused a concentration-dependent $\mathrm{Ca}^{2+}$ efflux of about $30-40 \%$ within 2 min.

Taken together, these findings demonstrate that stimulation of tyrosine phosphorylation by thrombin is dependent on cytosolic $\mathrm{Ca}^{2+}$.

\section{DISCUSSION}

In the present paper, we show that in $\mathrm{BC}_{3} \mathrm{Hl}$ cells thrombin enhances tyrosine phosphorylation of several proteins with relative molecular masses of 65-70 and 110-120 kDa (Figure 1). Depending on the degree of electrophoretic resolution, in some experiments the 65-70 $\mathrm{kDa}$ protein bands represent at least three different proteins (Figure 1).

Incubation of cells with the growth factors EGF, PDGF and insulin resulted in tyrosine phosphorylation of several proteins among which are species of the same molecular masses as found after treatment with thrombin. Phosphorylation of proteins with similar molecular masses in response to diverse agents suggests that these proteins play a role in the signal transduction of different agonists.

Proteins in the range of 65-70 and/or 110-120 kDa have also been reported to be phosphorylated on tyrosine residues by different mitogenic agonists in fibroblasts, liver epithelial cells and glomerular mesangial cells (Huckle et al., 1990; LeebLundberg and Song, 1991; Force et al., 1991), pointing to a general role for one or more of these proteins in the mitogenic response to diverse stimuli.

Whereas receptors of EGF, PDGF and insulin possess an intrinsic protein tyrosine kinase activity (Ullrich and Schlessinger, 1990), the thrombin receptor has recently been shown to belong to the family of G-protein-linked receptors activated by proteolytic cleavage near the $\mathrm{N}$-terminus (Vu et al., 1991b). In order to demonstrate that this G-protein-coupled thrombin receptor mediated the effect of thrombin, we tested whether hirudin, a potent thrombin inhibitor (Stone and Hofsteenge, 1986), prevented thrombin from stimulating tyrosine phosphorylation in $\mathrm{BC}_{3} \mathrm{Hl}$ cells (see Table 1). We additionally tested whether the thrombin receptor agonist peptide SFLLRN-NH ${ }_{2}$ was able to mimic the effect of thrombin (see Table 1). Since hirudin blocked the effect of thrombin and the receptor peptide mimicked the effect of thrombin, it is very likely that thrombin acts through its G-protein-coupled receptor.

Thrombin effects in several cells show different sensitivity to PT (Murayama and Ui, 1985; Grandt et al., 1986; Pouysségur et al., 1988), indicating that thrombin can act via PT-sensitive and -insensitive G-proteins. Stimulation of tyrosine phosphorylation by thrombin is obviously not mediated by a PT-sensitive Gprotein, since preincubation of cells with the toxin did not affect the action of different concentrations of thrombin. Kelvin et al. (1989) reported that stimulation of DNA synthesis by thrombin in $\mathrm{BC}_{3} \mathrm{Hl}$ cells is at least partially sensitive towards PT. Assuming that tyrosine phosphorylation is causally related to initiation of cell growth, the reason for this discrepancy is so far not clear. Thrombin-stimulated PT-insensitive tyrosine phosphorylation may not be the only path leading to stimulated DNA synthesis. The mitogenic action of different growth factors acting via Gprotein-coupled receptors seems to be mediated by multiple effectors (Rozengurt, 1986; Pouysségur, 1990).

To clarify further the mechanism by which thrombin induces tyrosine phosphorylation, we tested whether activation of phospholipase $\mathrm{C}$ with the resulting activation of PKC and increase in cytosolic $\mathrm{Ca}^{2+}$ is the mechanism that transduces thrombin receptor activation into tyrosine phosphorylation. Stimulation of PKC by phorbol esters leads to tyrosine phosphorylation in platelets, fibroblasts and vascular smooth muscle cells (Kazlauskas and Cooper, 1988; Ferrell and Martin, 1989; Tsuda et al., 1991). Moreover, growth factor-dependent tyrosine phosphorylation of mitogen-activated protein (MAP) kinase appears to be dependent on PKC (Vila and Weber, 1988; Rossomando et al., 1989). We found that also in $\mathrm{BC}_{3} \mathrm{H} 1$ cells, activation of PKC by PMA (Table 3) as well as 1,2-dioctanoyl$s n$-glycerol (not shown) resulted in tyrosine phosphorylation. The pattern of proteins phosphorylated at tyrosine residues in response to PKC activation was identical with that found after thrombin treatment. However, PKC activation was obviously not necessary for the effect of thrombin, since treatment of cells with the PKC inhibitor calphostin C did not affect the thrombinstimulated phosphorylation. Calphostin C, which in contrast with other PKC inhibitors (e.g. staurosporine) has a high selectivity for PKC over tyrosine kinases (e.g. p60 ${ }^{\mathrm{v}-\mathrm{src}}$ ) and cyclic 
AMP-dependent protein kinase (Tamaoki, 1991), totally prevented PMA from inducing tyrosine phosphorylation.

Since cytosolic $\mathrm{Ca}^{2+}$ was recently reported to be involved in protein tyrosine phosphorylation processes (Huckle et al., 1990; Vostal et al., 1991), we tested the effect of the $\mathrm{Ca}^{2+}$ ionophore A23187 on tyrosine phosphorylation (Figure 3). A23187 induced a similar pattern of tyrosine phosphorylation to thrombin. Furthermore, the stimulation of tyrosine phosphorylation by thrombin could be totally blocked by loading the cells with the $\mathrm{Ca}^{2+}$ chelator BAPTA (Figure 3 ) but was unaffected by chelating the extracellular $\mathrm{Ca}^{2+}$ by EGTA (not shown). Thus the effect of thrombin appears to be dependent on cytosolic $\mathrm{Ca}^{2+}$. This is supported by the finding that neither the stimulation of tyrosine phosphorylation nor the mobilization of $\mathrm{Ca}^{2+}$ by thrombin in $\mathrm{BC}_{3} \mathrm{H} 1$ cells was affected by treatment of cells with PT (Table 2 and Figure 4). $\mathrm{Ca}^{2+}$ may regulate tyrosine kinases or phosphotyrosine phosphatases directly or by a $\mathrm{Ca}^{2+} /$ calmodulinmediated mechanism. The latter possibility is supported by our preliminary data, showing that naphthalenesulphonamide calmodulin antagonists can at least partially reduce the effect of thrombin on tyrosine phosphorylation. However, tyrosine kinases or phosphotyrosine phosphatases regulated by $\mathrm{Ca}^{2+}$ or $\mathrm{Ca}^{2+} /$ calmodulin have not yet been described. It is also conceivable that the effect of thrombin on tyrosine phosphorylation is mediated by other $\mathrm{Ca}^{2+}$-regulated mechanisms, e.g. serine/threonine phosphorylation or activation of phospholipases D or $\mathrm{A}_{2}$ (Edelman et al., 1987; Thompson et al., 1991; Sharp et al., 1991).

In conclusion, in $\mathrm{BC}_{3} \mathrm{H} 1$ cells thrombin stimulates tyrosine phosphorylation of several proteins. Proteins of identical molecular masses were phosphorylated at tyrosine residues by several polypeptide growth factors, suggesting that thrombin shares intermediates in the signalling pathway with recognized tyrosine kinase-linked growth factors. The effect of thrombin was not mediated by activation of PKC but was fully dependent on cytosolic $\mathrm{Ca}^{2+}$ concentration. Elucidation of the precise mechanism by which cytosolic $\mathrm{Ca}^{2+}$ mediates stimulation of tyrosine phosphorylation will be the aim of future work.

We thank Inge Reinsch for cell culture and Dr. Karsten Spicher for help in preparing antisera. This work was supported by the Deutsche Forschungsgemeinschaft and the Fonds der Chemischen Industrie.

\section{REFERENCES}

Akiyama, T. and Ogawara, H. (1991) Methods Enzymol. 201, 362-370 Berkow, R. L. and Dodson, R. W. (1991) J. Leukocyte Biol. 49, 599-604 Brown, R. D., Berger, K. D. and Taylor, P. (1984) J. Biol. Chem. 259, 7554-7562 Chambard, J. C., Paris, S., L’Allemain, G. and Pouysségur, J. (1987) Nature (London) 326, 800-803
Chen, L. B. and Buchanan, J. M. (1975) Proc. Natl. Acad. Sci. U.S.A. 72, 131-135

Dhar, A., Paul, A. K. and Shukla, S. D. (1990) Mol. Pharmacol. 37, 519-525

Edelman, A. M., Blumenthal, D. K. and Krebs, E. G. (1987) Annu. Rev. Biochem. 56, $567-613$

Fain, J. N., Wallace, M. A. and Wojcikiewicz, R. J. H. (1988) FASEB J. 2, 2569-2574

Ferrell, J. E. and Martin, G. S. (1989) J. Biol. Chem. 264, 20723-20729

Force, T., Kyriakis, J. M., Avruch, J. and Bonventre, J. V. (1991) J. Biol. Chem. 266, $6650-6656$

Gilmore, T. and Martin, G. S. (1983) Nature (London) 306, 487-490

Golden, A. and Brugge, S. (1989) Proc. Natl. Acad. Sci. U.S.A. 86, 901-905

Gomez-Cambronero, J., Wang, E., Johnson, G., Huang, C.-K. and Sha'afi, R. I. (1991) J. Biol. Chem. 266, 6240-6245

Grandt, R., Aktories, K. and Jakobs, K. H. (1986) Biochem. J. 237, 669-674

Huang, C.-K., Bonak, V., Laramee, G. R. and Casnellie, J. E. (1990) Biochem. J. 269, $431-436$

Huckle, W., Prokop, C. A., Dy, R. C., Herman, B. and Earp, S. (1990) Mol. Cell. Biol. 10 $6290-6298$

Hui, K. Y., Jakubowski, J. A., Wyss, V. L. and Angleton, E. L. (1992) Biochem. Biophys. Res. Commun. 184, 790-796

Hunter, T. and Cooper, J. A. (1985) Annu. Rev. Biochem. 54, 897-930

Kamps, M. P. and Sefton, B. M. (1988) Oncogene 2, 305-315

Kazlauskas, A. and Cooper, J. A. (1988) J. Cell Biol. 106, 1395-1402

Kelvin, D. J., Simard, G., Sue-A-Quan, A. and Connolly, J. A. (1989) J. Cell Biol. 108, 169-176

Leeb-Lundberg, L. M. and Song, X.-H. (1991) J. Biol. Chem. 266, 7746-7749

Markwardt, F. (1970) Methods Enzymol. 19, 924-932

Meldrum, E., Parker, P. J. and Carozzi, A. (1991) Biochim. Biophys. Acta 1092, 49-71

Murayama, T. and Ui, M. (1985) J. Biol. Chem. 260, 7226-7233

Offermanns, S., Seifert, R., Metzger, J. W., Jung, G., Lieberknecht, A., Schmidt, U. and Schultz, G. (1992) Biochem. J. 282, 551-557

Pouysségur, J. (1990) in G-proteins (lyengar, R. and Birnbaumer, L., eds.), pp. 555-570, Academic Press, San Diego

Pouysségur, J., Chambard, J. C., L'Allemain, G., Magnaldo, I. and Seuwen, K. (1988) Philos. Trans. R. Soc. London 320, 427-436

Rozengurt, E. (1986) Science 234, 161-166

Rossomando, A. J., Payne, D. M., Weber, M. J. and Sturgill, T. W. (1989) Proc. Natl. Acad. Sci. U.S.A. 86, 6940-6943

Sharp, J. D., White, D. L., Chiou, G., Goodson, T., Gamboa, G. C., McClure, D., Burgett, S., Hoskins, J., Skatrud, P. L., Sportsman, J. R., Becker, G. W., Kang, L. H., Roberts, E. F. and Kramer, R. M. (1991) J. Biol. Chem. 266, 14850-14853

Stone, S.-R. and Hofsteenge, J. (1986) Biochemistry 25, 4622-4628

Takuwa, N., Takuwa, Y., Yanagisawa, M., Yamashita, K. and Masaki, T. (1989) J. Biol. Chem. 264, 7856-7861

Tamaoki, T. (1991) Methods Enzymol. 201, 340-347

Thompson, N. T., Bonser, R. W. and Garland, L. G. (1991) Trends Pharmacol. Sci. 12 404-408

Tsuda, T., Kawahara, Y., Shii, K., Koide, M., Ishida, Y. and Yokoyama, M. (1991) FEBS Lett. 285, 44-48

Ullrich, A. and Schlessinger, J. (1990) Cell 61, 203-212

Vila, J. and Weber, M. J. (1988) J. Cell. Physiol. 135, 285-292

Vostal, J. G., Jackson, W. L. and Shulman, N. R. (1991) J. Biol. Chem. 266, 16911-16916

Vu, T.-K. H., Hung, D. T., Wheaton, V. I. and Coughlin, S. R. (1991a) Cell 64, 1057-1068

Vu, T.-K. H., Wheaton, V. I., Hung, D. T., Charo, I. and Coughlin, S. R. (1991b) Nature (London) 353, 674-677

Yarden, Y. and Ullrich, A. (1988) Annu. Rev. Biochem. 57, 443-478

Zachary, I., Woll, P. and Rozengurt, E. (1987) Dev. Biol. 124, 295-308

Zachary, I., Gil, J., Lehmann, W., Sinnett-Smith, J. and Rozengurt, E. (1991) Proc. Natl. Acad. Sci. U.S.A. 88, 4577-4581

Received 24 April 1992/26 August 1992; accepted 2 September 1992 